\title{
Photovoltaic Industry Progress from 1980 through 1986
}

June 1987

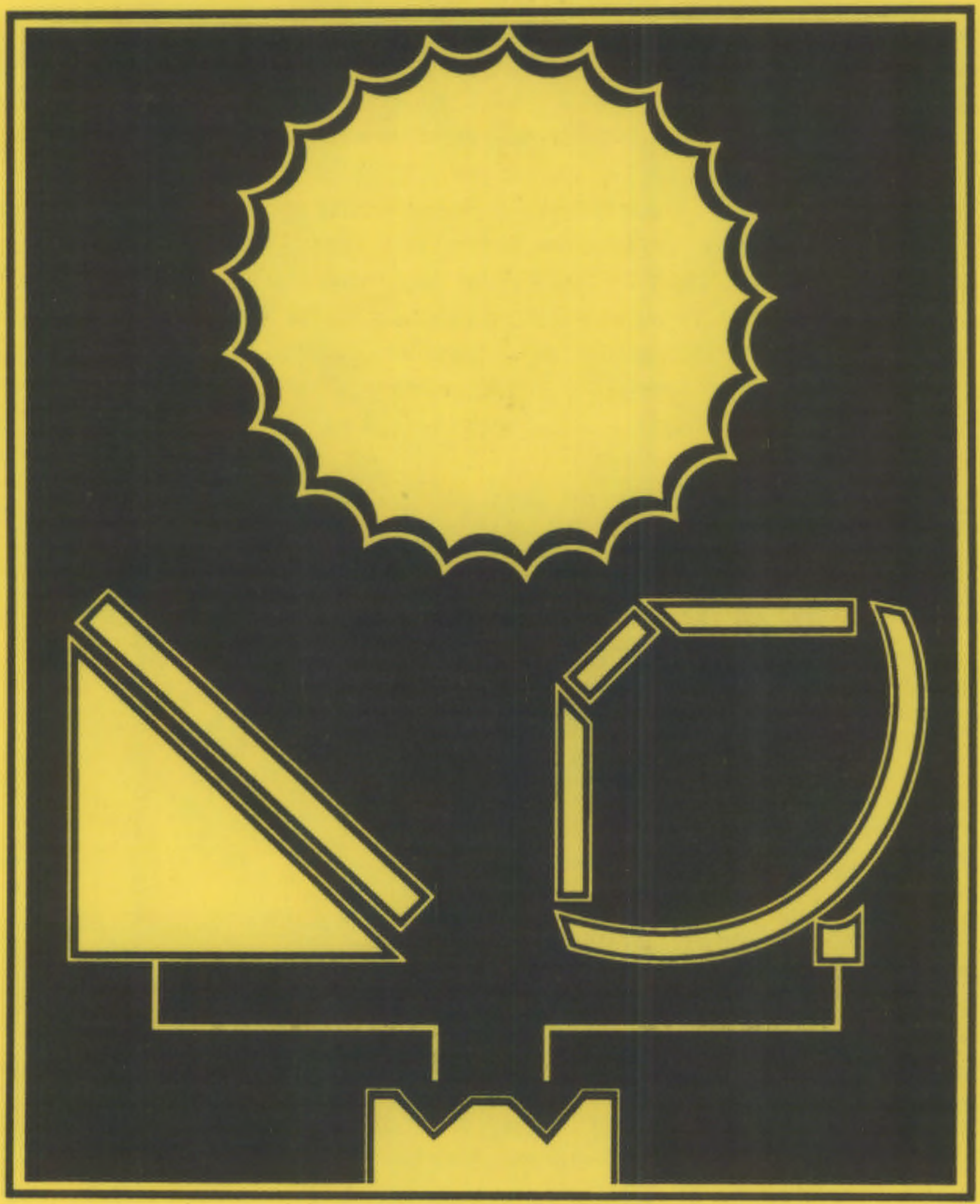

Prepared for the U.S. Department of Energy under Contract DE-AC06-76RLO 1830

Pacific Northwest Laboratory

Operated for the U.S. Department of Energy

by Battelle Memorial Institute 


\section{DISCLAIMER}

This report was prepared as an account of work sponsored by an agency of the United States Government. Neither the United States Government nor any agency thereof, nor Battelle Memorial Institute, nor any of their employees, makes any warranty, expressed or implied, or assumes any legal liability or responsibility for the accuracy, completeness, or usefulness of any information, apparatus, product, or process disclosed, or represents that its use would not infringe privately owned rights. Reference herein to any specific commercial product, process, or service by trade name, trademark, manufacturer, or otherwise, does not necessarily constitute or imply its endorsement, recommendation, or favoring by the United States Government of any agency thereof, or Battelle Memorial Institute. The views and opinions of authors expressed herein do not necessarly state or reflect those of the United States Government or any agency thereof, or Battelle Memorial Institute.

\section{PACIFIC NORTHWEST LABORATORY operated by BATTELLE MEMORIAL INSTITUTE for the \\ UNITED STATES DEPARTMENT OF ENERGY under Contract DE-ACO6-76RLO 1830}

\begin{tabular}{|c|c|}
\hline \multicolumn{2}{|c|}{$\begin{array}{l}\text { Printed in the United States of America } \\
\text { Available from } \\
\text { National Technical Information Service } \\
\text { United States Department of Commerce } \\
5285 \text { Port Royal Road } \\
\text { Springfield, Virginia } 22161\end{array}$} \\
\hline \multicolumn{2}{|c|}{$\begin{array}{l}\text { NTIS Price Codes } \\
\text { Microfiche A01 }\end{array}$} \\
\hline \multicolumn{2}{|c|}{ Printed Copy } \\
\hline Pages & $\begin{array}{l}\text { Price } \\
\text { Codes }\end{array}$ \\
\hline $001-025$ & $\mathrm{~A} 02$ \\
\hline $026-050$ & A03 \\
\hline $051-075$ & $\mathrm{~A} 04$ \\
\hline $076-100$ & A05 \\
\hline $101-125$ & $A 06$ \\
\hline $126-150$ & A07 \\
\hline $151-175$ & A08 \\
\hline $176-200$ & $\mathrm{~A} 09$ \\
\hline $201-225$ & A010 \\
\hline $226-250$ & A011 \\
\hline $251-275$ & $\mathrm{~A} 012$ \\
\hline $276-300$ & A013 \\
\hline
\end{tabular}


Photovoltaic Industry Progress

from 1980 through 1986

R. L. Watts

S. A. Smith

June 1987

Prepared for the U.S. Department of Energy under Contract DE-AC06-76RLO 1830

Pacific Northwest Laboratory Richland, Washington 99352 


\section{Contents}

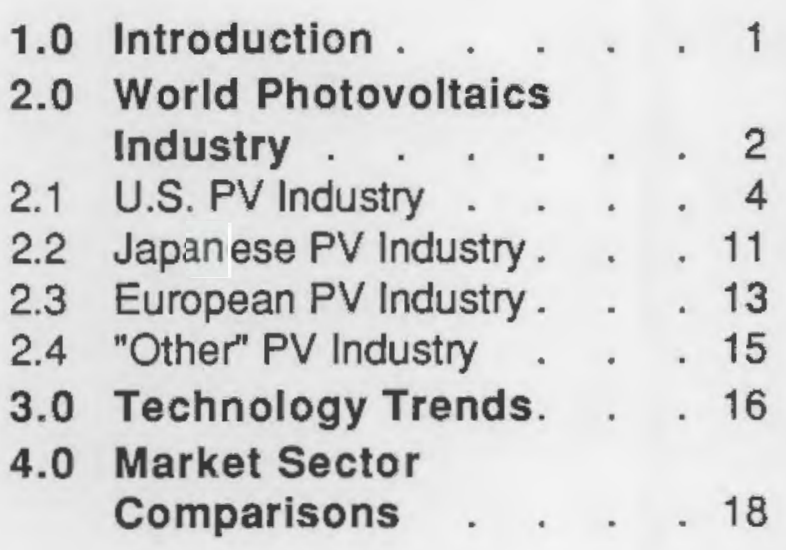

Figure 2.1: World PV Shipments . . 2

Figure 2.2: Total PV Revenue . . . 3

Figure 2.3: Regional Market Share for Total PV Shipments vs.

Power Module Shipments . . . . 4

Figure 2.4: U.S. PV Shipments . . . 5

Figure 2.5: Subsidized and Nonsubsidized U.S. Shipments. . . 5

Figure 2.6: World PV Market Share . . 6

Figure 2.7: Japanese PV Shipments. . 11

Figure 2.8: European PV Shipments. . 13

Figure 3.1: Technology Distributions of World PV Shipments . . . 16

Figure 4.1: PV Shipments to the
Stand-Alone Market Sector . . 20

Figure 4.2: PV Shipments to the
Consumer Market Sector. . . 21

Figure 4.3: Market Sector Distribution of World PV Shipments . 21
Table 2.1: World PV Shipments . . . 2

Table 2.2: Summary of World PV

Shipments According to Strategies

Unlimited . . . . . . 3

Table 2.3: Summary of World

PV Shipments According to

Photovoltaic Energy Systems, Inc. . . 3

Table 2.4: Summary of World PV Shipments According to

Photovoltaic Insiders Report . . . 3

Table 2.5: U.S. Module
Manufacturers in 1986 . . . . 6

Table 2.6: Major Japanese Module Manufacturers in 1986.11

Table 2.7: Major European Module Manufacturers in $1986 . \quad . \quad 13$

Table 3.1: Distribution of PV Shipments by Technology. . . 16

Table 3.2: PV Manufacturers Using CZ in 1986

Table 3.3: PV Manufacturers Using Semicrystalline Technology in 1986 .

Tabie 3.4: PV Manufacturers Using a-Si Technology in 1986 . . . 18

Table 4.1: Shipments to End-Use Market Sectors . . . . 19

Table 4.2: Grid-Connected PV Shipments 


\section{Summary}

From 1980 through 1985 the world photovoltaics (PV) market has grown at an average annual rate of $44 \%$. The market continued to grow during the past year with shipments increasing from 20.5 megawatts (MW) in 1985 to $24.7 \mathrm{MW}$ in 1986. This increase, which occurred in spite of the decline in government and tax-sheltered purchases, indicates a strengthening of the commercial PV market.

Prices paid by distributors for crystalline PV modules dropped from $\$ 7 / \mathrm{Wp}$ in 1984 to $\$ 5.25 / \mathrm{Wp}$ in 1986. This price decline appears to be the result of increased competition from both Japanese and European firms, and does not appear to nave resulted from comparable reduction in production costs.

This sharp increase in competition in power module production has made survival more difficult for smaller U.S. PV manufacturers. A major U.S. PV manufacturer, Solavolt International, withdrew from the commercial marketplace in 1986. Other U.S. manufacturers reduced the number of their production employees. Energy Conversion Devices (ECD) lost the financial support of Standard Oil of Ohio (SOHIO) and, as a result, reduced its $\mathrm{PV}$ operations.

Meanwhile, Japanese producers continued to dominate the world consumer goods PV market, while the United States continued to dominate the world PV power module market. This dominance by the U.S. in the power module market is expected to continue through 1987.
The decrease in U.S. government-subsidized sales/purchases was nearly equalled by the increase in crystalline silicon module shipments for stand-alone applications and by the increase in amorphous silicon (a-Si) cells used in electronic consumer goods. Four U.S. companies marketed a-Si power modules in 1986. Most U.S. a-Si sales were for modules of approximately $5 \mathrm{~W}$ rating; although, 25-35 $\mathrm{W}$ modules were selectively available. Consequently, a-Si modules were not a major factor in the commercial market in 1986. However, a-Si modules are expected to become more important in 1987 as their availability, reliability, and efficiency improves. ARCO Solar Inc. announced that it is designing a plant capable of producing $70 \mathrm{MW}$ of thin film PV per year.

Most commercial emphasis is focused on developing the a-Si technology in spite of impressive technical advances in other PV technology options. PV concentrators continue to represent only a small portion of the total PV market. Mobil Solar Inc., the only commercial U.S. supplier of ribbon reduced both its PV marketing and production effort. Westinghouse is considering entering the ribbon marketplace. Proven reliability and impressive gains in conversion efficiencies of crystalline silicon flat plate PV modules will assure their continued dominance of the commercial power module market for some time in the future as they present a challenging moving target to competing technologies. 


\section{Acknowledgments}

The report was prepared with the cooperation of ANDREW KRANTZ and VINCENT RICE of the U.S. Department of Energy's Photovoltaics Division, and the various companies and individuals that comprise the U.S. photovoltaics industry. Special assistance in gathering primary industry data was provided by PAUL. MAYCOCK of Photovoltaic Energy Sytems, Inc., and by DR. KATSUNORI SHIMADA of the Jet Propulsion Laboratory. 


\subsection{Introduction}

The growth of the U.S. photovoltaics (PV) industry from 1980 to 1986 has been impressive. In that period, the industry dramatically improved the quality of the products offered for sale, while reducing manufacturing costs and selling price. Initially designed to provide power for satellites using high-cost processes, PV is now the economical choice for supplying electrical power in many remote terrestrial applications. The remarkable growth of $P V$, in the quality of cells and modules, production techniques, and system design, was led by a cooperative effort of the U.S. government and domestic PV manufacturers.

European and Japanese firms entered the PV industry later than the United States, but are also growing rapidly. The European firms supply PV systems for village electrification and water pumping to many Third World countries, in addition to supplying traditional markets such as PV-powered communications equipment, corrosion protection, and remote residences.

The Japanese industry followed an approach totally different from U.S. and European manufacturers, concentrating on very small cells used to power calculators, watches, and other consumer products. These small cells add up to an area equivalent to many MW of PV power modules, and the experience gained in small cell manufacture certainly adds to the technology base available to the Japanese for an assault on the power module market.

The objective of this report is to describe PV industry developments through 1986. Information is presented on a regional basis (United States, Europe, Japan, other) to avoid disclosing company confidential data. Information was gleaned from several sources, including a review of technical literature and direct contacts with many PV manufacturers. Before the regional totals were published, all numbers were compared with those from other sources published in the United States and those supplied by Japanese industry through their solar energy organization.

The information in this report is prepared for use by the U.S. Department of Energy (DOE) in longrange planning activities. However, this information should also be of interest to PV manufacturers and those who may be contemplating entry into the PV market.

This report is divided into four chapters. Chapter 2.0 summarizes PV shipments for 1986. Chapter 3.0 presents technology trends and Chapter 4.0 presents trends in the market sectors receiving PV shipments. 


\subsection{World Photovoltaics}

\section{Industry}

The world photovoltaics industry continued to grow in 1986, with shipments of cells and modules increasing from $20.5 \mathrm{MW}^{*}$ in 1985 to approximately $25 \mathrm{MW}$ (Figure 2.1). Total world PV shipments remained relatively flat during 1983,1984 , and 1985 , and the market seems to have stagnated during this three year period. Within total shipments, however, large shifts have occurred in 1) the regions producing the $P V, 2)$ the technologies being produced and 3) the market sectors receiving those shipments. The following sections outline these shifts in more detail.

Japan moved ahead of the United States, for the first time in 1985 and continued to grow in 1986, with total PV shipments of $11.3 \mathrm{MW}$ compared with the U.S. total of $7.6 \mathrm{MW}$ (Table 2.1). Japan's lead is mainly due to their nearly complete dominance of the consumer goods PV market; whereas, the United States clearly leads in production of PV power modules. Europe remained fairly constant with shipments in the range of 3 to $4 \mathrm{MW}$ for the past 4 years.

Thin film technologies made little impact in the form of power module shipments in spite of the continuing focus of commercial research and development (R\&D) on amorphous silicon (a-Si) and other thin films. Concentrator production virtually stopped in 1986 despite impressive technical achievements resulting in increases in overall efficiency. The commercial marketplace picked up most of the slack caused by the loss of approximately $3 \mathrm{MW}$ of "tax-shelter" concentrator business in 1985.

Industry revenue increased to about $\$ 380$ million in 1986 from $\$ 360$ million in 1985 (Figure 2.2). These revenue figures do not include investments in PV R\&D or in production equipment, although balance of systems equipment is

"Does not include shipments of cells or modules for space applications.

\section{FIGURE 2.1 \\ World PV Shipments}

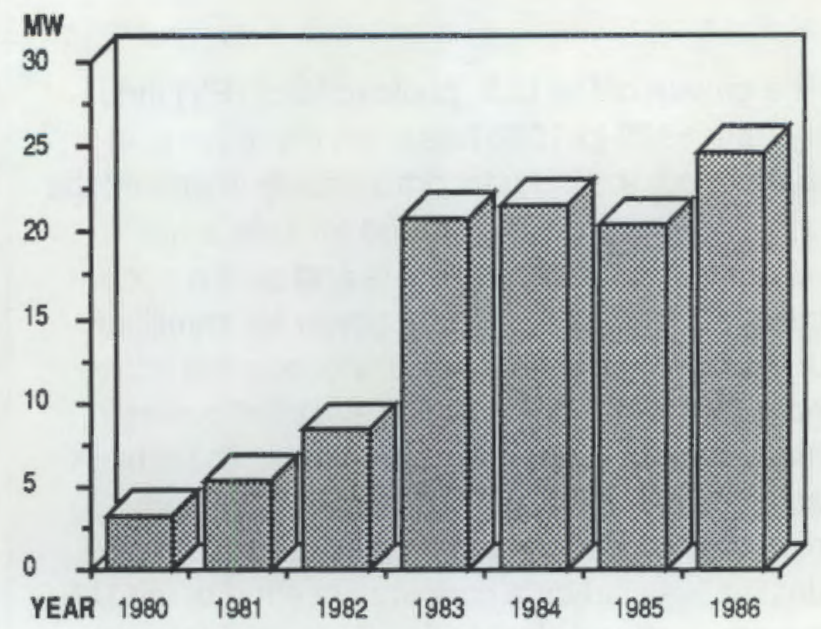

TABLE 2.1

World PV Shipments (MW)

Begion $\quad 1980198119821983198419851986$

U.S.

\begin{tabular}{|c|c|c|c|c|c|c|c|}
\hline Flat Plate & 2.5 & 2.6 & 4.3 & 8.1 & 8.4 & 7.6 & 7.6 \\
\hline Concentrato & $\leq 1$ & 0.9 & $\underline{0.9^{*}}$ & $4.6^{*}$ & $3.1^{*}$ & 0.1 & $\leq 0$. \\
\hline Total U.S. & 2.5 & 3.5 & 5.2 & 12.7 & 11.5 & 7.7 & 7.6 \\
\hline Japan & 0.5 & 1.1 & 1.7 & 4.3 & 6.2 & 8.1 & 11. \\
\hline Europe & 0.3 & 0.8 & 1.4 & 3.3 & 3.3 & 3.5 & 4.0 \\
\hline Other & 0.0 & 0.0 & 0.1 & 0.5 & 0.6 & 1.2 & 1. \\
\hline Total & 3.3 & 5.4 & 8.4 & 20.8 & 21.6 & 20.5 & 24 \\
\hline
\end{tabular}

- These figures contain substantial quantities of "tax shelter" shipments.

included. The price of power modules to distributors buying in large quantities decreased from about $\$ 7 \mathrm{Wp}$ in 1984 to $\$ 5.25 / \mathrm{Wp}$ by 1986 (measured in current dollars).

Traditional commercial markets continue to show substantial growth, but require considerable investment in customer education and market development for each increment of new business. 
FIGURE 2.2

Total PV Revenue

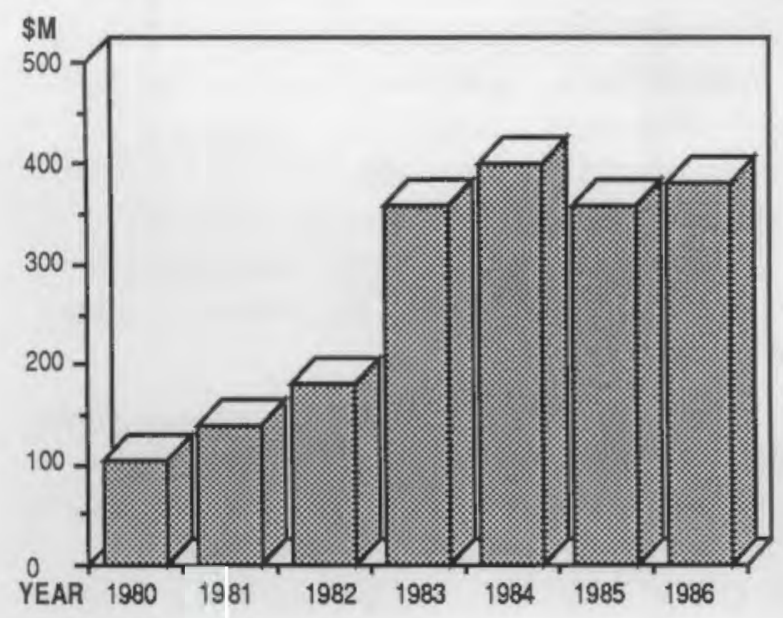

New technologies that promise large reductions in power module production costs are still being produced in small quantities. Modules manufactured using new production methods cost more than the single-crystal silicon (CZ) and semi-crystalline modules they replace. In addition, modules made using new techniques have the disadvantage of a less certain life and stability characteristics.

Other estimates of world PV shipments are available from several sources. Estimates of world PV shipments for 1983 through 1986 published by Strategies Unlimited are included in Table 2.2. Estimates by Photovoltaic Energy Systems, Inc. for 1983 through 1986 are included in Table 2.3. Estimates by Photovoltaic Insiders Report for 1985 and 1986 are included in Table 2.4.

These estimates differ primarily because of differences in accounting for the output of mirroraugmented modules and in estimating the output of modules used in consumer goods. The regional trends of the PV industry are discussed in the sections immediately following.
TABLE 2.2

Summary of World PV Shipments (MW) According to Strategies Unlimited

$\begin{array}{lrrrr}\text { Region } & 1983 & 1984 & \underline{1985} & 1986 \\ \text { U.S. } & 9.3 & 8.5 & 7.5 & 7.2 \\ \text { Japan } & 3.8 & 6.6 & 6.4 & 8.2 \\ \text { Europe } & 2.2 & 2.6 & 3.7 & 3.4 \\ \text { Other } & \frac{0.3}{0.8} & \underline{0.8} & 1.8 & \underline{3.2} \\ \text { Total } & 15.6 & 18.5 & 19.4 & 22.0\end{array}$

Source: Best, D. 1985."Profiling 1984's World Market". Solar Age, April, 1985, p. 22-23.

TABLE 2.3

Summary of World PV Shipments (MW) According to Photovoltaic Energy Systems, Inc.

$\begin{array}{lrrrr}\text { Region } & 1983 & \underline{1984} & 1985 & 1986 \\ \text { U.S. } & 13.1 & 11.7 & 8.5 & 7.5 \\ \text { Japan } & 5.0 & 8.9 & 10.8 & 13.4 \\ \text { Europe } & 3.3 & 3.6 & 3.7 & 4.3 \\ \text { Other } & \underline{0.3} & \underline{0.8} & \underline{1.4} & \underline{2.3} \\ \text { Total } & 21.7 & 25.0 & 24.4 & 27.5\end{array}$

Source: Maycock, P. 1987. Photovoltaic News, February, 1986, Vol. 5, No. 2, p. 2.

TABLE 2.4

Summary of World PV Shipments (MW) According to Photovoltaic Insiders Report

\begin{tabular}{lrr} 
Begion & 1985 & 1986 \\
\cline { 2 - 3 } U.S. & 10.0 & 11.0 \\
Japan & 11.0 & 12.5 \\
Europe & 4.5 & 4.7 \\
Other & 1.5 & 1.7 \\
Total & 27.0 & 29.9
\end{tabular}

Source: Photovoltaic Insiders Report. Richard Curry ed., Vol. VI, No. 2, February 1987, p. 6. 


\subsection{U.S. PV Industry}

The United States clearly dominated the world commercial PV industry from 1980 to 1984 (Table 2.1). However, in 1985 Japan took the lead in overall shipments if consumer goods uses are included in the totals. The United States continues to lead in the production of power modules (Figure 2.3).

Total U.S. shipments remained virtually unchanged from 1985 to 1986 (Figure 2.4). Although U.S. shipments declined from 1984 to 1985 , the United States continues to lead in PV power module technology, and was the first to introduce a-Si modules to the commercial power module market.

The U.S. commercial market is dominated by two companies, ARCO Solar, and Solarex. ARCO Solar continued to be the world leader in PV manufacturing in 1986, serving a variety of commercial markets including central station applications. These gains largely offset losses in tax subsidies and direct government purchases.
Solarex made similar adjustments to the changed market environment.

Most of the decline in U.S. shipments between 1984 and 1985 is the result of the United Energy Corporation's decision to end tax-sheltered thirdparty sales of concentrator technology in December of 1984. Besides this loss of concentrator sales, other factors contributing to the decline in PV shipments include a reduction in government purchases and the phase-out of tax incentives.

During 1983 and 1984 the U.S. market was stimulated by a combination of direct government purchases and third-party-financed purchases (Figure 2.5). These shipments amounted to $8.5 \mathrm{MW}$ in 1983 ( $70 \%$ of U.S. shipments), which is viewed as a conservative estimate since it excludes residential systerns sales that may have been dependent on the tax incentives. By 1984, federally subsidized shipments had decreased to about 5.5 MW and continued to decrease in 1985 and 1986 to about $1.5 \mathrm{MW}$.

There were substantial increases in the domestic and export market for conventional, stand-alone PV applications in 1984 and continued strength in

FIGURE 2.3

Regional Market Share for

Total PV Shipments vs.

Total Power Module Shipments

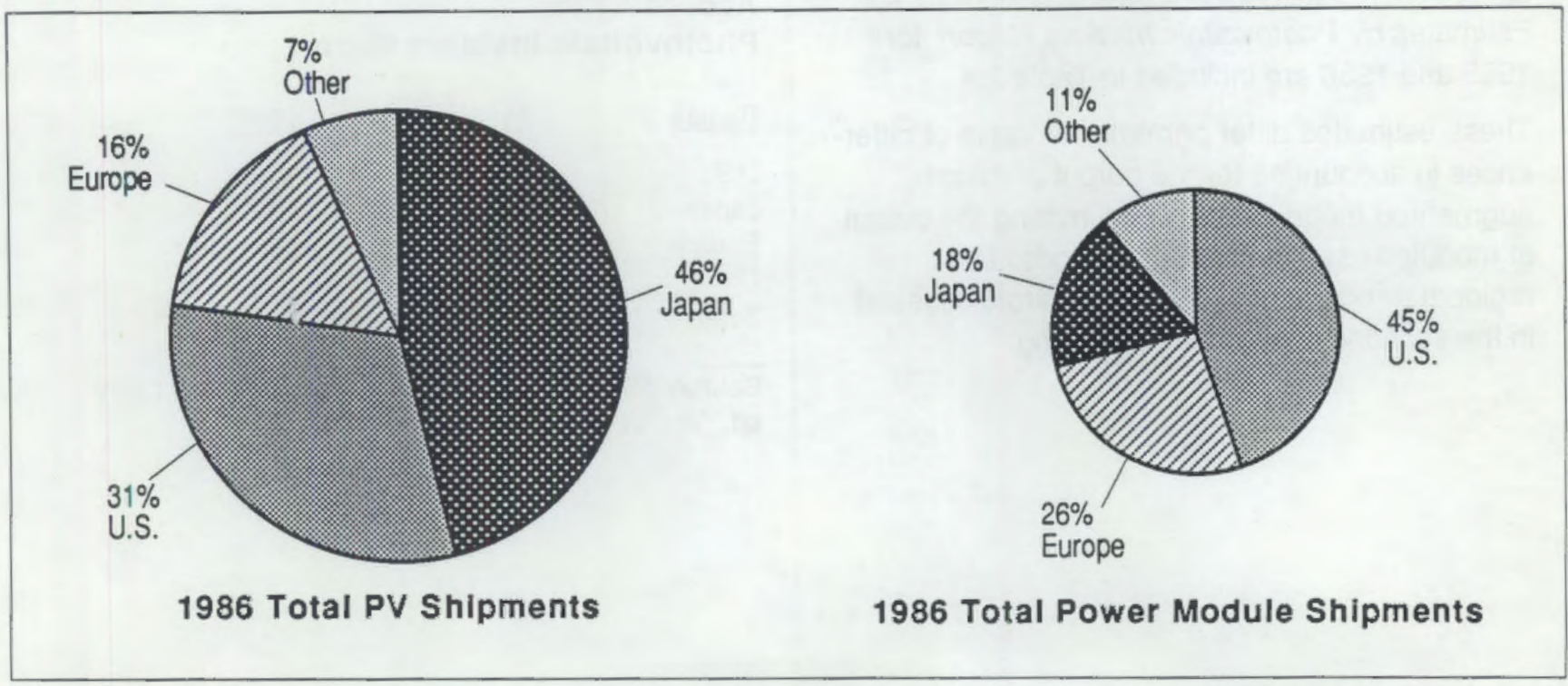


these market sectors during 1985 , increasing from about $4 \mathrm{MW}$ in 1983 to about $6.2 \mathrm{MW}$ in 1985.

These increases would be larger except for the relatively strong dollar, the continuing shortage of money in the international markets, and the increased competition from Europe and Japan.

Overall, the U.S. share of the market dropped from $58 \%$ in 1983 to $37 \%$ in 1985 and to $31 \%$ in 1986 (Figure 2.6).

During the early 1980 's, module prices for large government purchases were in the range of $\$ 10$ to $\$ 12 / W p$ (as measured in current dollars). By 1983 , module prices bid on large contracts had fallen to about $\$ 5 / \mathrm{Wp}$ (SMUD II bids).

Throughout 1984, price competition was moderate at the retail level. During 1985 and the first half of 1986 , prices at the retail distributor level on quantities in the range of 100 modules had fallen from about $\$ 7 / W p$ to a little more than $\$ 5 / W p$ due to increased competition. A $300-\mathrm{kW}$ grid-connected system was bid at $\$ 8.88$, including balance of systems costs.

PV production costs have not declined sufficiently during the last 3 years to provide adequate profits to module manufacturers. Unprofitable operations forced several firms to reorganize and consolidate their operations:

- Photowatt-left the PV industry in 1983

- Solar Power Corp.-left the PV industry early in 1984

FIGURE 2.4

\section{U.S. PV Shipments}

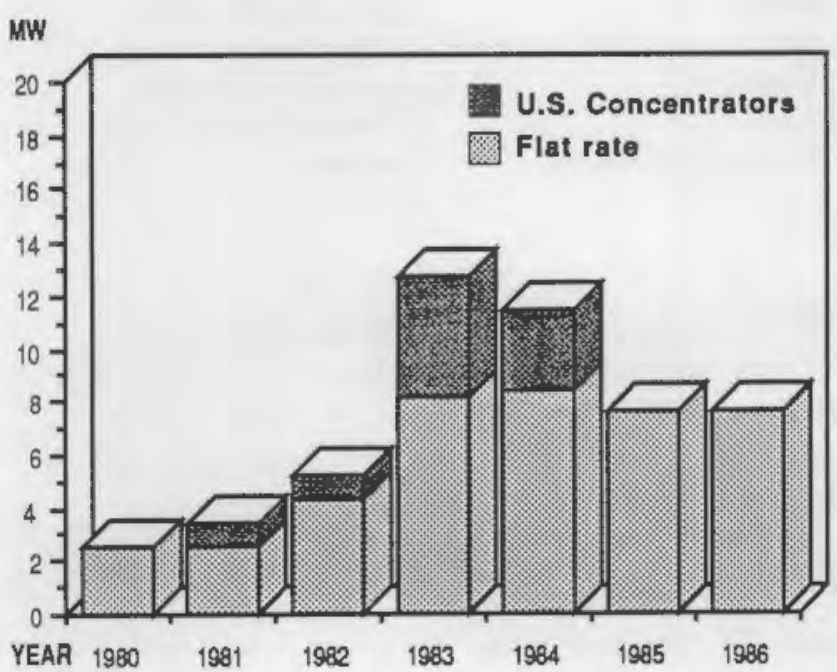

- Solarex-purchased by Standard Oil of Indiana (AMOCO) in 1983 (Solarex name continued)

- Applied Solar Energy Corp.-shifted emphasis from terrestrial PV to space in 1982

- E-Systems-sold its PV division to its employees, who renamed the company ENTECH in 1983

- Martin-Marietta-left the PV industry in 1984

- Solarex-reduced staff by 100 employees in 1984 and further consolidated operations in 1985

- ARCO Solar-reduced staff by approximately 140 employees in 1984 and further consolidated operations in 1985

- Solenergy-left the PV industry in 1985

- Solec International-Pilkington Bros. withdrew from Solec (sold interest to the founder)

- United Energy Corporation-filed for Chapter 11 in 1985

- Sovonics (jointly owned by SOHIO and ECD) disbanded with operations consolidated at ECD in 1986

- ECD-reduced its number of employees and PV budget in 1986

- Solarex-experienced sluggish PV sales and is reducing staff by $10 \%$ in 1986

FIGURE 2.5

\section{Subsidized and Nonsubsidized U.S. Shipments}

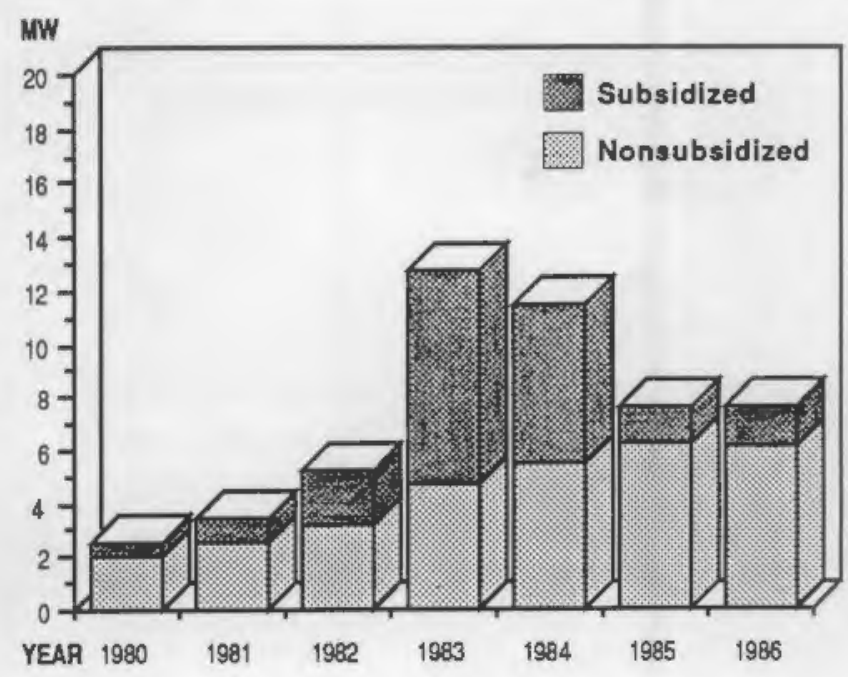


6 FIGURE 2.6

World PV Market Share

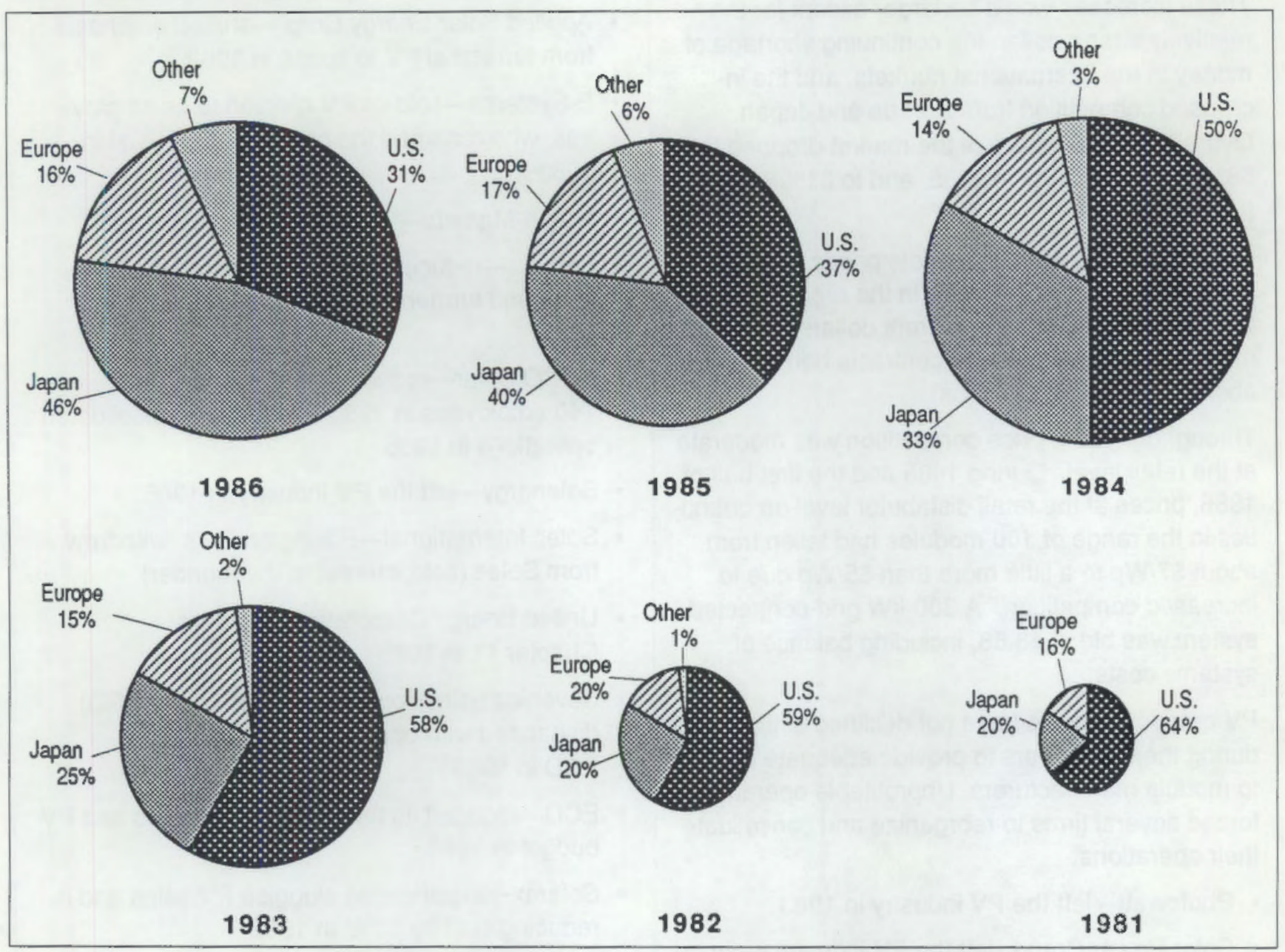

- Mobil Solar-reduced their production and marketing of PV.

- Solavolt International-lett the PV industry in early 1987.

However, the long-term prospect of a growing PV market has attracted the interest of several companies, including

- Polaroid

- 3M

- Glasstech

- Astrosystems

Table 2.5 lists PV module manufacturers in the United States during 1986. The following section provides background iniormation on selected U.S. manufacturers.
TABLE 2.5

U.S. Module Manufacturers in 1986

$\begin{array}{ll}\text { ARCO Solar } & \text { Mobil Solar Energy } \\ \text { Chronar } & \text { Solarex Corporation } \\ \text { Energy Conversion Devices/ } & \text { Solavolt International } \\ \text { Sovonics } & \text { Solec International } \\ \text { Entech } & \text { Tideland Signal Corp. } \\ \text { Free Energy Systems } & \text { Intersol }\end{array}$

ARCO Solar, Inc. This company is the leading PV manufacturer in the world and is a subsidiary of the Atlantic Richfield Company. In 1978, ARCO Solar, Inc., purchased a small PV manufacturer, Solar Technology International, which had been founded 3 years earlier. ARCO proceeded to install a modern, semi-automated assembly line to produce $\mathrm{CZ}$ cells and modules. 
In January 1980, ARCO signed a multimillion dollar product development and licensing agreement with Energy Conversion Devices, Inc. (ECD), aimed at accelerating the commercialization of EDC's a-Si thin film devices. In May 1981, ARCO decided to allow the ECD PV contract to expire and decided to support its own a-Si R\&D.

During 1983, ARCO built the first 1-MW central station PV system in Hesperia, California, using CZ technology, and announced plans for a 16MW PV facility at Carissa Plains.

In 1984, ARCO introduced the world's first commercial a-Si power module, the "Genesis." This module is more than $5 \%$ efficient and carries a 1-year warranty. ARCO also increased the warranty on many of its single-crystal silicon power modules to 10 years, and received the Underwriters Laboratories approval on its M53 and M73 modules. ARCO laid-off about 140 of their 600 employees during 1984; however, most lay-olfs were not in research areas.

During 1985, ARCO continued an aggressive approach to selling $\mathrm{CZ}$ modules while strengthening their a-Si product line. They were awarded a $\$ 2.7$ million contract with the city of Austin, Texas to provide a $300-\mathrm{kW}$ system. The price of the entire $\mathrm{CZ}$ system is $\$ 8.88 / \mathrm{Wp}$. They announced a $30-W$ a-Si monolithic power module early in 1986. In addition ARCO has announced translucent a-Si film modules for a variety of uses such as in automobile sun-roofs, clocks and other consumer products. Also, a-Si production facilities were consolidated at Camarillo, California, and capacity has been increased to $1 \mathrm{MW} / \mathrm{yr}$. ARCO is designing an a-Si plant capable of producing $70 \mathrm{MW} / \mathrm{yr}$. The new plant is scheduled to start operation in 1988.

During 1986 ARCO signed partnership agreements with two foreign companies, Showa Shell and Interatom. Showa Shell will be involved in building and operating a fully automated PV facility in Tokyo, Japan. The design of the facility will be based on ARCO's thin film manufacturing process. Modules produced will be marketed through Singapore. Interatom signed an agreement setting guidelines for cooperation in the field of $\mathrm{PV}$ product technology. ARCO is planning to establish a European manufacturing facility.
Chronar Corporation. This company is a major supplier of equipment to manufacturing ventures. This company was incorporated in 1976 with the purpose of developing commercial PV manufacturing facilities. To date, Chronar has developed a batch process for producing a-Si cells and modules. Through joint venture agreements, Chronar has sold PV production equipment to several organizations.

- AFG Industries-In 1983, AFG Industries signed an agreement to install a 1-MW production line in Tennessee. Chronar retained $51 \%$ ownership and AFG $49 \%$. Financing for the sale came from $\$ 5$ million in industrial revenue bonds.

- Port Jervis, New York-Chronar and a group of private investors joined to establish a batch processing facility. This $\$ 6$ million installation was opened in December 1984, and is currently producing a-Si modules at a manufacturing cost of $\$ 2 / W$.

An important milestone in the use of a-Si in power modules was established in June 1986 with the completion of a $100-\mathrm{kW}$ installation for Alabama Power. The modules were manufactured in the Port Jervis, New York, plant.

- Alabama Power-This company a subsidiary of the Southern Company that signed an agreement with Chronar in March 1984 to build a batch processing facility. Alabama Power will pay $\$ 6.1$ million for $85 \%$ ownership in the joint venture, and Chronar will pay $\$ 1.1$ million for $15 \%$ ownership.

- Chronar Ltd., Bridgend, Wales-This wholly owned subsidiary was financed through grants and low-interest loans from Wales. The 1-MW facility opened April 17, 1985.

- Chronar France-This plant is owned by Chronar, SOMDIAA, Charbonnages de France, and Groupe Drout. The \$10-million, 1-MW facility began producing a-Si modules in late 1985.

- Chronar China-This facility will cost $\$ 10$ million and will have a production capacity of $1 \mathrm{MW} / \mathrm{yr}$. A 10 ton/yr silane manufacturing plant will be built near the PV facility. 
During 1984, Chronar increased their systems capability, acquiring Tri-Solar Corporation, an experienced manufacturer of PV-powered pumping systems. In 1985 and 1986 they announced a number of PV systems and consumer products powered by a-Si.

Chronar's stock is sold through the over-thecounter market and is reported in the NASDAO exchange under the symbol CRNR. In March 1987 , the stock had a market value of $\$ 13.25$ / share.

Energy Conversion Devices (ECD). This company manufactures a-Si power modules. ECD was established in 1960 and has developed a continuous roll production technique for a-Si cells. The development of this technique was partially funded by $\$ 9.3$ million received from ARCO in 1980. This technology was incorporated into the production equipment that was sold to a Sharp/ ECD joint venture of Japan.

ECD established two partnership agreements with SOHIO, (1981), a technology partnership and an operating partnership called Sovonics Solar Systems. The goals of these agreements are to 1) perform further research on the production of PV cells, 2) to commercialize the PV technology, and 3 ) to grant royalty-bearing leases. Since 1981, SOHIO has contributed $\$ 85$ million to ECD through their operating partnership; however, in $1986 \mathrm{SOHIO}$ announced its withdrawal from the partnership.

During 1984, Sovonics Solar Systems announced its plans to build a cell production facility in Michigan and a module assembly plant in Ohio. Sovonics also signed a memorandum of understanding with China to establish a joint venture to manufacture and market a-Si cells. During 1986, however, the Sovonics venture was absorbed into the ECD operation in Michigan as a result of the SOHIO withdrawal. Also, 25-30 people were terminated as a result of the PV budget being cut from $\$ 22$ million in 1985 to $\$ 10$ million in 1986 . ECD has announced that production will continue at the Michigan facilities.

ECD stock is traded on the over-the-counter market under the symbol ENER. In March 1987, the stock had a market value of $\$ 25 /$ share. ECD currently employs 459 full-time employees, approximately 100 involved with PV.

ENTECH. Entech currently manufactures and sells PV concentrator systems that use high efficiency fresnel lens. The system that ENTECH developed can provide either electricity or a combination of electricity and hot water. In June of 1982, an ENTECH concentrator system was installed at the Dallas/Fort Worth airport. ENTECH is also actively involved in the research and development of concentrating collectors, modules and system design improvements.

In 1986 Entech bid on a $\$ 100$ million contract to build and install a 30-MW PV system near Lake Havasu, Arizona. The system is sponsored by the Council of Energy Resource tribes in Chemahuevi, California.

Glasstech Solar Inc. Glasstech Solar is a privately owned company that began a-Si production lines in 1985. Their production lines are capable of producing up to $10 \mathrm{MW} / \mathrm{yr}$ of a-Si cells, assuming three shifts per day. They also custom design a-Si production lines for R\&D applications.

INTERSOL Power Corporation. This company currently manufactures concentrator $\mathrm{PV}$ systems and was started by former employees of Martin Marietta Corporation of Denver.

In 1985 Virginia Electric Power Company selected the INTERSOL 2 Axis tracker for its test facility. The tracker will be used to compare the power generated by fixed, single and double axis tracking systems.

Mobil Solar Energy Corporation. Mobil Solar manufactures PV power modules using ribbon technology. This company was originally a joint venture formed in 1974 by Tyco Laboratories, Inc. $(20 \%)$, and Mobil Oil Corporation (80\%). In 1983 , Mobil purchased Tyco Laboratories' interest in the company and the company was renamed Mobil Solar Energy Corporation. The parent organization, Mobil Corporation, was incorporated in 1882 and is a major energy company ( $\$ 60$ billion in sales in 1984), with products and services in oil, gas, chemicals, and paperboard.

After several years of R\&D, Mobil opened a new manufacturing facility as a part of a major expansion plan to produce $10 \mathrm{MW}$ per year within the next few years. In 1983, Mobil introduced a new ribbon production technology. This technique produces a nine-sided tube of silicon that is cut by a laser to produce rectangular cells. 
During 1984, Mobil was awarded a $\$ 245,000$ contract to supply $37 \mathrm{KW}$ of ribbon silicon modules for Phase II of the SMUD project. In 1986, five of their modules received Underwriters Laboratories safety approval.

In 1986 Mobil Solar announced that it was reducing both its PV marketing and production efforts while concentrating on technology development.

Solec International, Inc. This small business was started in 1976 by Ishaq Shahrayer to manufacture PV celis and modules. In 1980, Pilkington Brothers, a British glass manufacturer, purchased $80 \%$ interest in Solec. This acquisition benefited Solec because it provided the company with worldwide sales outlets. Solecs sales increased by $300 \%$. Subsequently, Pilkington Bros. sold their interest back to Ishaq Shahrayer in 1985. Currently, Solec purchases wafers, manufactures cells and panels, and markets a variety of PV systems. Solec employs approximately 50 people.

Solenergy Corporation. This was a small, privately held business established in 1978 by Robert Willis to manufacture PV devices. Solenergy purchased silicon slices, produced a wide variety of products, and had a staft of 25 people.

Kayex Corporation was a $20 \%$ shareholder in the company. Kayex is a General Signal Corporation company specializing in material processing equipment for the PV and silicon industries, and has annual sales of about $\$ 20$ million.

In 1983, Solenergy merged with Entropy, Ltd., via a stock exchange, and in 1984 they signed a letter of intent with China to build a PV manufacturing plant. In 1985 Solenergy stopped manufacturing PV modules.

Spire Corporation. Founded in 1969 as a small business, this high-technology company is engaged in researching, engineering, and manufacturing PV cells and processing equipment for high-volume production of cells and modules.

The company has produced cells and modules for the DOE PV program, but its primary interest is manufacturing $P V$ production equipment. The company is also developing thin film processes for low-cost substrate fabrication, thin film deposition, and cell structure formation. In 1983, Spire began to sell its SPI-LINE ${ }^{\text {TM }}$ system to Saudia Arabia and to India.
Spire also developed a process for depositing GaAs directly onto a silicon substrate that may significantly reduce the cost of GaAs cells. Spire signed a $\$ 4$ million agreement with China in 1984 to sell $1 \mathrm{MW}$ of PV manufacturing equipment, and they have sold a 1-MW PV module manufacturing system to Solarpac of Canada.

Spire Corporation stock is traded on the NASDAQ exchange under the symbol SPIR. In March 1987 the stock had a market value of $\$ 10.25 /$ share.

Solarex Corporation. Solarex Corporation entered the PV industry in 1973, and soon became known for its technological leadership with developments such as the most efficient solar cell, the first high-density modules, vertical junction cells and the ultra light 2-mil cell for space PV applications. The most significant development was the semicrystalline silicon material for solar cell use. Before this development, single-crystal silicon was the only material used for solar cell mass production. Solarex started a wholly owned subsidiary. Semix, to manufacture the semicrystalline material.

Until 1983, Solarex was a widely held company with corporate investors from countries such as Italy, Holland, and France. In 1983, Solarex became a totally owned subsidiary of Standard Oil Company (Indiana) and Semix became a division of Solarex Corporation.

Solarex has a manufacturing facility in Australia (Solarex Pty) and one in Hong Kong (Solarex Electric) for consumer products. It has a sales office in Milan, Italy, to handle sales in Europe, the Middle East, and Africa, in addition to sales outlets coast-to-coast in the United States.

In 1983, Solarex acquired RCA's a-Si technology and formed the Thin Film Division. The Solarex Thin Film Division was the first U.S. company to commercially manufacture and ship amorphous products.

Solarex also has an Aerospace division that manufactures solar cells for use on satellites and spacecraft and was chosen to supply the PV modules for NASA's COBE spacecraft.

Solarex had approximately 600 employees in 1984. The number of employees decreased in 1985 and 1986 while production has increased, and refiection of improved operating efficiency. 
Solarex shipped the first a-Si cells for use in calculators made in the United States and continues an aggressive program to increase the efficiency of its production cells and to introduce them in other markets.

Solarex sold several intermediate-sized PV systems in 1986. However, sluggish sales worldwide resulted in $10 \%$ of their staff being laid-off.

Solavolt International. This company was formed as a joint venture between Motorola ( $\$ 5$ billion in sales in 1984) and Shell Oil Company subsidiaries ( $\$ 21$ billion in sales in 1984) in 1981. Both companies had been working in PV since the mid-1970s.
Solavolt originally had two divisions: one to concentrate on thin film technologies and the second to develop their continuous ribbon production process. The thin film research was phased out in 1983.

They used conventional and polycrystalline silicon technology to produce high-quality modules to gain both production and marketing experience.

Solavolt had planned to introduce their ribbon modules within the next year, which could replace polycrystalline modules with very similar performance, reliability and life characteristics. However, in early 1987 Solavolt decided to leave the PV industry citing their inability to reduce ribbon-to ribbon production costs to a competitive level. 


\subsection{Japanese PV Industry}

The Japanese PV industry has grown rapidly over the past five years from $0.5 \mathrm{MW}$ of shipments in 1980 to $11.3 \mathrm{MW}$ in 1986 (Figure 2.7). However, unlike U.S. shipments, about $80 \%$ of the Japanese sales are to the nonsubsidized, consumer goods market, which includes PV cells to power watches, calculators, radios, etc. The Japanese companies have viewed this market as a testing ground for developing their thin film technology, as weil as a means of expanding their PV production base. By concentrating on the consumer goods market, the Japanese share of the world PV market has increased from $15 \%$ in 1980 to $46 \%$ in 1986 (Figure 2.6).

Although the Japanese have increased their share of the world PV market, they are still behind the rest of the world in producing large-scale PV power modules. However, they are in the process of closing the gap; they are developing and producing more single-crystal and semicrystalline modules and are making a determined bid to penetrate the U.S. market with an attractive product line. They apparently do not intend to risk exclusion from the power market by limitations subsequently encountered in the perfection of high-efficiency a-Si power modules. The Japanese government is providing money through the Sunshine project to eliminate this technology gap.

FIGURE 2.7

\section{Japanese PV Shipments}

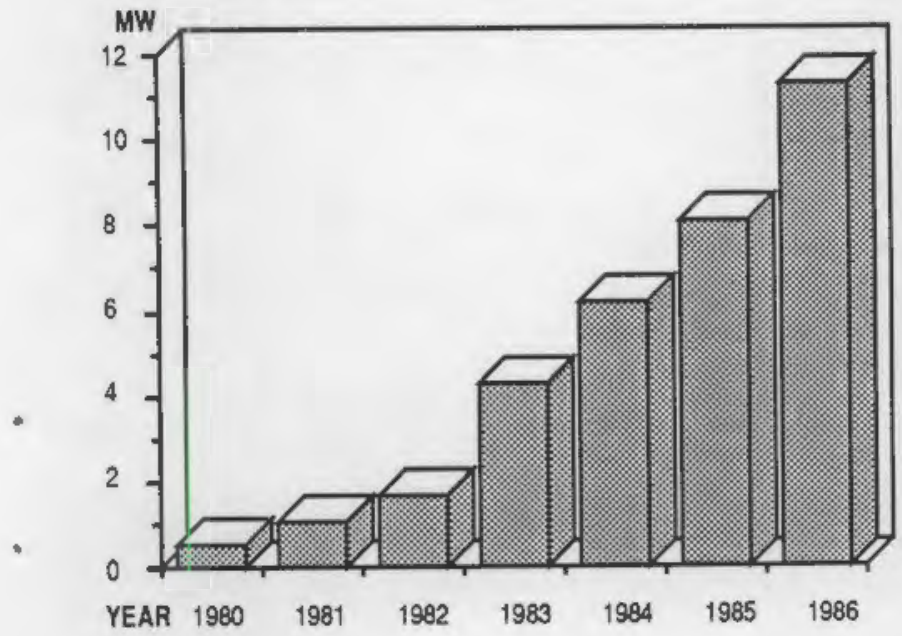

Table 2.6 lists the Japanese manufacturers in 1986. The following section provides background information on major Japanese module manufacturers.

Fujl Electric was one of the first Japanese PV companies to fabricate large area a-Si cells on a metallic substrate. Fuji has also constructed a PV residence that uses $3 \mathrm{~kW}$ of modules and a Fuji Power conditioning system. During 1984, Fuji signed an agreement to share a-Si developments with Photowatt of France. Fuji is the second leading world producer of a-Si modules for use in calculators and watches, and is developing an interdigital vertical electrode process for depositing a-Si.

Hoxan started in 1929 in Sapporo, Hokkaida Province as an oxygen production plant. Hoxan has grown to be a manufacturer of a wide range of industrial and specialty gases, liquid petroleum gas, medical gases and handling equipment.

In 1963, in a joint venture with American Standard, they began production of Bath-All bathroom units. In 1982, Hoxan entered the PV industry with modest production. They recently have completed a 9-MW, fully automated PV production facility. Claiming to be the largest PV manufacturing facility in the world, this facility converts single-crystal silicon slices into 36 -cell, $40 \mathrm{~W}$ modules. A unique feature of this plant is that it is completely automated.

Hoxan and American Standard of the United States have announced a joint venture called Heliopower, Inc. to market PV in 1986.

TABLE 2.6

\section{Major Japanese Module Manufacturers In 1986}

Fuji Electric Co. Hitachi Eiectric Co.

Mitaka Electronics

Hoxan Co.

Mitsubishi

Japan Solar Energy Co.

Kanekafugi

Kodenshi

Komatsu Electronics

Kyocera

Nippon Electric

Sanyo Electric

Sharp

Showa Oil Co.

Taiyo Yuden

Toshiba 
Kyocera entered the photovoltaics industry in 1979 and has produced modules in the four major PV technologies: polycrystalline silicon, singlecrystal silicon, a-Si and ribbon. Their ribbon PV technology was developed through a joint venture with Mobil Solar (then Mobil Tyco) in 1979. Kyocera entered the U.S. market vigorously in 1984 selling both modules (multicrystalline) and systems.

In 1986 Kyocera increased the warranty on its complete line of modules to ten years. Plans were also initiated to begin producing polycrystalline $\mathrm{Si}$ instead of buying it from Wacker.

Sanyo is the leading producer of PV in Japan. Sanyo has established an energy division involved in both PV and solar thermal technologies. It constructed a $\$ 50$ million $\mathrm{PV}$ production plant capable of producing more than 1 million calculator-type modules per month. Sanyo plans to begin producing a-Si power modules in 1987.

Sharp has been in the PV business longer than any other Japanese firm. Currently, Sharp is the principal manufacturer of PV cells for Japanese spacecraft. The company is also involved in manufacturing crystaline cells and modules for use in remote stand-alone applications and a-Si pocket calculators.

They joined ECD (USA) in developing a roll-to-roll a-Si production machine that fabricates a-Si cells on a $180-\mathrm{cm}$ wide stainless steel sheet. During 1986, Sharp installed PV system in 3 Thailand villages. The systems totaled $150 \mathrm{~kW}$. 


\subsection{European PV Industry}

Shipments of PV modules by European firms increased from $0.3 \mathrm{MW}$ in 1980 to approximately $4 \mathrm{MW}$ in 1986 (Figure 2.8). There appears to be a slight growth in shipments between 1984 and 1985 in spite of greatly reduced purchases of modules by the Commission of European Communities (CEC). The CEC has assisted European PV manufacturers in establishing 15 pilot projects under cost-sharing arrangements. The major portion of shipments to these projects occurred in 1983 and 1984; therefore, maintaining modest overall growth required substantial increases in nonsubsidized shipments. The reduction in purchases in 1985 by CEC resulted from delays in finalizing the budget for PV projects for the next five years.

Table 2.7 lists major European module manufacturers in 1986. The following section provides background information on these manufacturers.

AEG. AEG has been involved in PV for the past 20 years and is currently Germany's largest PV manufacturer. In the past, AEG purchased polycrystalline Si from other manufacturers for their PV modules. However, AEG has been working with Heliotronic, a Wacker Chemitronic subsidiary, on the development of low-cost polycrystalline silicon.
Currently, AEG markets a wide range of PV systems such as hazard beacons, water pumping systems, and telecommunications relay stations. AEG was the primary contractor for the $300-\mathrm{kW}$ Pellworm Island PV system that was partially funded by the CEC. AEG supplied the PV modules for the British satellite, Giotto.

Ansaldo. Ansaldo is a state-owned electromechanical company appointed by the government of Italy to develop and produce energy systems. They manufacture their own single-crystalline cells and produce PV modules. Currently, PV production capacity is about $200 \mathrm{~kW}$. Some research is being conducted on a-Si; however, they have no plans to introduce a-Si modules in the near future. Ansaldo has been involved in the construction of a $1-\mathrm{kW}$, hybrid thermaVPV plant in Australia.

BP Solar. Prior to 1983, BP Solar was a joint venture between British Petroleum (BP) and Lucas. In 1983, BP purchased Lucas' interest in the company. Currently they purchase cells and produce modules. Their marketing objective is to sell complete PV systems not individual modules.

In 1983 BP Solar began installing the largest PV system in the U.K. near Southampton. The $30-\mathrm{kW}$ installation is estimated to cost $\$ 1.5$ million and is financed by BP Solar and the Department of Industry. During 1984, BP Solar acquired the film division of Monosolar as well as the technology to manufacture the mercury, telluride and cadmium/ telluride cells.

TABLE 2.7

Major European Module Manufacturers in 1986
AEG
Isophoton
Adriatica Componenti
Photowatt SA
Ansaldo
BP Solar
Pragma
Siemens A.G.

Helios Technology 
In 1985 BP Solar acquired the Tideland Energy Pty., Ltd., manufacturing plant from Tideland USA, giving them an Australian manufacturing capacity of $100 \mathrm{~kW}$ per year.

BP Solar is marketing aggressively in the communications field in 1985 and 1986. BP Solar announced sale of 5000 modules to Peru for 38 microwave repeater stations. The total installed capacity is to be rated at $165 \mathrm{~kW}$.

France Photon. France Photon is a wholly owned subsidiary of Leroy-Somers, a mediumsized electrical company with 4000 employees. The subsidiary was formed in 1978 to produce single and polycrystalline cells and modules using the Solarex technology. The design and marketing of complete PV systems is performed by two other Leroy-Somers groups: Pompes Guinard and Systemes Solaires.

France Photon has built a $44 \mathrm{~kW}$ village electric system at Rondolinu Cargese, Corsica. France Photon merged their PV operations into Photowatt SA in 1985.

Helios. Helios is located in Italy and is one of the few non-oil, nongovernment-funded module producers in Europe. Helios purchased PV technology from Solec International and has an advanced, low-cost, automated cell and module manufacturing line. Helios has been a major cell supplier for BP Solar, and they have concentrated their marketing efforts in southem Europe.

Photowatt, SA. This company is a subsidiary of SAFT (CGE group), ELF (a major oil company) and RTC (the Philips group), with its headquarters located in Revie-Malmaison, near Paris. Photowatt has also established Photowatt Afrique, in Abidjan, Ivory Coast, to sell small PV-powered systems to neighboring countries.
In 1984, Photowatt took steps toward commercializing the "polyx" ingot casting process developed by Photowatt and Laboratories de Marcousses. Photowatt manufactured about $50 \%$ of their modules in 1985 and $100 \%$ of their modules in 1986 using Polyx multicrystalline silicon. By switching to the Polyx multicrystalline, Photowatt expects to be able to achieve the PV cost reduction goals set by the govemment agency, Agence Francaise Pour la Maitrise de l'Energie, of $\$ 2.75 / \mathrm{Wp}$.

Pragma. Pragma of italy was formed by the state-owned oil company ENI. Pragma originally owned a share of Solarex and therefore had access to the technology for producing "Semix" polycrystalline material. Pragma also owns a controlling interest in Solarix, an Italian licensee of Solarex.

Pragma has assembled both single-crystal and polycrystalline modules. They are working on a-Si. They reported at the end of 1983 that they had sold their production quota for 1984. Previously they had announced a capacity of $450 \mathrm{~kW}$ per year. They built an automated assembly plant for cells and modules capable of producing $2 \mathrm{MW} / \mathrm{yr}$.

Slemens A.G. Interatom, a subsidiary of Siemens was responsible for all PV research, product development and marketing. Siemens' product development strategy has four major elements: quality single-crystal modules, R\&D on low-cost silicon purification using arc furnace technology, high-spead ribbon production using web-supported horizontal growth, and a-Si R\&D.

Their single-crystal product is marketed worldwide and is used for communications, battery charging, remote residential power, etc. Siemens currently employs approximately 40 professionals in its $\mathrm{PV}$ business. 


\section{4 "Other" PV Industry}

The "other" PV industry includes primarily those PV companies in Asia and South America. The growth in PV activity in this region has been modestly increasing from $400 \mathrm{~kW}$ in 1983 to $1.8 \mathrm{MW}$ in 1986. Two companies are responsible for much of the growth of this region: CEL and Heliodynamica.

CEL. (New Delhi, India). CEL is a govemmentowned PV manufacturer that produces crystalline PV cells, modules, and systems. The technology used was developed in the United States, but the production equipment was made in India.

CEL has developed and manufactured PV systems for offshore well-head platforms, telecommunications, weather monitoring and various other industrial applications. In 1986 CEL developed a pocketsized PV module to power transistor radios and toys, and a PV backpack for village power.
Heliodynamica. Located in Cotia, Brazil $(22$ miles 15 from Sao Paulo), this company is a privately owned PV manufacturer that entered the PV industry in 1980. Heliodynamica is the first Third World company to manufacture cells, modules and complete PV systems.

They installed Brazil's first PV-powered water pumping system in 1981 at Rio Grade del Norte. The company has since developed a new motor for its submersible tube well pump as well as an extremely simple priming device for its surfacemounted pumps. Telebras, the government telecommunications company, is replacing many of its diesel generators at remote sites with PV powered systems, supplied by Heliodynamica.

In 1986 Heliodynamica introduced PV-powered refrigerators in Brazil, and they won an international bid to supply India with 350,000 silicon wafers.

The following countries have small PV production facilities:

- Saudi Arabia

- China

- Canada. 


\subsection{Technology Trends}

During 1986, commercial PV modules were made from cells using five different technologies: singlecrystal silicon (CZ), amorphous silicon (a- Si), semicrystalline silicon (semi-XTL), concentrators, and ribbon. Single-crystal silicon continues to be the dominant PV technology with $49 \%$ of the market in 1986 (Figure 3.1). CZ production has been quite stable (approximately $10 \mathrm{MW}$ ) from 1983 through 1986 (Table 3.1). This stability in the face of challenges by other technologies reflects its continued strength in a number of market sectors.

Semicrystalline cells were used in module production in steadily increasing quantities from 1980 to 1984 and leveled off in 1985 and 1986.
TABLE 3.1

Distribution of PV Shipments (MW) by Technology

Technology $1980 \underline{1981} 1982 \underline{1983} \underline{1984} 1985$ 1986 Single $\begin{array}{llllllll}\text { Crystal } & 1.9 & 2.5 & 4.5 & 9.9 & 9.6 & 9.9 & 12.1\end{array}$

Semi-

$\begin{array}{llllllll}\text { crystalline } & 1.0 & 1.3 & 2.1 & 3.2 & 4.5 & 4.5 & 4.2\end{array}$

Amorphous

$\begin{array}{llllllll}\text { Silicon } & 0.3 & 0.6 & 0.8 & 3.0 & 4.3 & 5.8 & 8.2\end{array}$

Concen-

$\begin{array}{llllllll}\text { trators } & 0.0 & 0.9 & 0.9 & 4.6 & 3.1 & 0.1 & <0.1\end{array}$

Ribbon \&

$\begin{array}{llllllll}\text { Other } & 0.1 & 0.1 & 0.1 & 0.1 & 0.1 & 0.2 & 0.2\end{array}$

Totals

\section{FIGURE 3.1}

\section{Technology Distributions of World}

PV Shipments

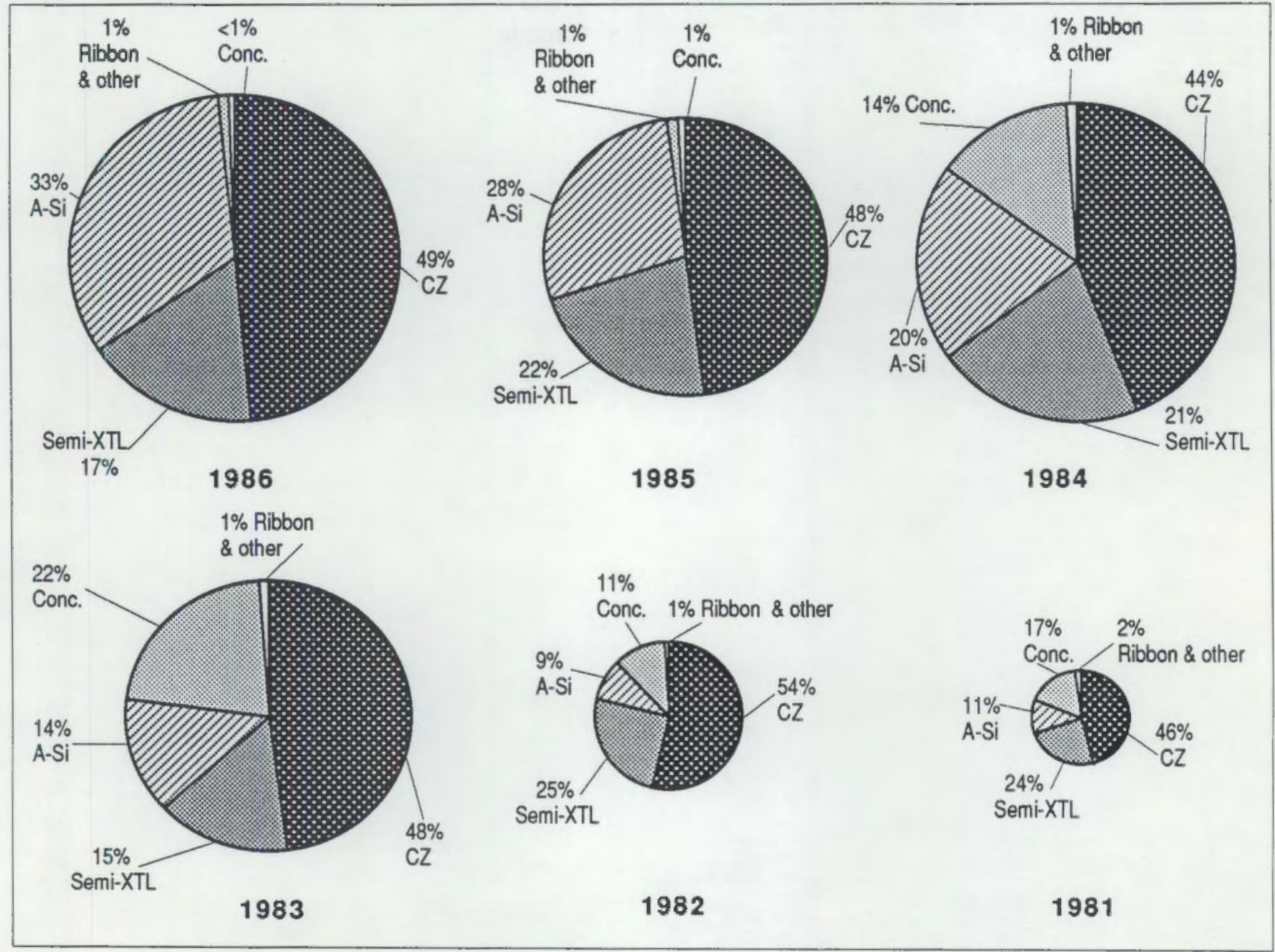


The efficiency of this technology has increased steadily with, production modules being about 1 percentage point less efficient on an area basis compared with $\mathrm{CZ}$ modules.

Together single crystal and semicrystalline technologies have accounted for about two-thirds of the total market for 1983 to 1986 . Their market share might have eroded more rapidly than has actually occurred if both technologies had not made substantial improvements in their conversion efficiency and reliability.

Amorphous silicon thin film shipments have been increasing steadily due to the growth of the consumer goods market. However, a-Si has not seriously penetrated the power module market. This may change as modules larger than $5 \mathrm{~W}$ were available for the first time in 1985 and 1986. Most of these larger modules go to a few selected applications where their pertormance and stability can be carefully monitored. These modules may begin to penetrate some of the present flat plate market sectors in 1987.

Amorphous silicon is expected to penetrate first into those markets where efficiency does not directly affect the computed balance of system costs. Numerous applications not yet widely used by the conventional technologies could greatly increase the size of this market. Some of these uses include automotive applications to provide battery topping and interior ventilation. Other sectors such as communications and corrosion protection will probably continue for some time to come to use products that have gone through a lengthy qualification procedure.

During 1986 a-Si modules were tested in a gridconnected utility application by Alabama Power. A $100-\mathrm{kW}$ (rated) system was installed to test its performance and compatibility with the utility's power system. The system is capable of providing sufficient electriciiy for 25 homes.

The U.S. Department of Energy continues to support the development of a-Si technology by funding research through the Solar Energy Research Institute (SERI). Since 1983 SERI has coordinated the Amorphous Silicon Research Program (ASRP), an industrial cost-sharing research activity. One milestone of this effort was the achievement of an $8 \%, 1000 \mathrm{~cm}^{2}$ submodule

conversion efficiency by Solarex Corp. and a $5 \%$, $2790 \mathrm{~cm}^{2}$ submodule conversion etficiency by Chronar Corp. The ASRP is expected to continue through 1990.

The concentrator technology is slowly penetrating the PV market, with several systems being installed in 1986. The lack of interest in concentrator systems is attributed to the view, held by many small system buyers, that concentrators are technically more complicated than flat plate systems. Larger systems have involved federal tax credits or other forms of subsidy. In the recent legislative climate, tax incentives and other subsidies have become less attractive, causing a loss of most of the concentrator market. Brilliant technical achievements in increasing the efficiency of concentrator systems have not been able to counter this trend.

Other technologies, including ribbon technologies, have achieved modest market penetration $(300 \mathrm{~kW})$. The ribbon technologies have great potential for cost reduction compared with the costs for making conventional $\mathrm{CZ}$ or semicrystalline cells. Manufacturers of ribbon technologies have made considerable progress in improving the technology and reducing the manufacturing cost. They have more than matched the efficiency and expected costs of the $\mathrm{CZ}$ modules of the past. In 1986 Westinghouse announced plans for increasing the capacity of their dendritic web ribbon pilot line. They are, however, aiming at a moving target due to the great progress made by $\mathrm{CZ}$ and semicrystalline technology. Other technologies such

TABLE 3.2

PV Manufacturers Using CZ in 1986

Acrian

Ansaldo

ARCO Solar

BHEL

BP Solar

Central Electronics Ltd. Continental Devices

Energia Tideland

Free Energy Systems

Heliodynamica

Helios Technology

Hoxan

Isophoton
Kodenshi

Komatsu Electronics

Nippon Electric

Photowatt SA

Pragma

Sharp

Showa Oil Co.

Siemens AG

Silicon Sensors

Solec International

Spire Corporation

Tideland Signal 
TABLE 3.3

PV Manufacturers Using Semicrystalline

Technology in 1986

$\begin{array}{ll}\text { Adriatica Componenti } & \text { Kyocera } \\ \text { AEG Telefunken } & \text { Pragma } \\ \text { Hitachi } & \text { Solarex Corporation } \\ \text { Hoxan } & \text { Solarex Pty. Ltd. } \\ \text { Japan Solar Energy } & \text { Solavolt Intemational } \\ \text { Komatsu Electronics } & \end{array}$

TABLE 3.4

PV Manufacturers Using a-Si Technology in 1986

$\begin{array}{ll}\text { Sanyo Electric } & \text { Chronar \& Licensees } \\ \text { Sharp } & \text { ECD } \\ \text { Solarex } & \text { Fuji Electric } \\ \text { Taiyo Yuden } & \text { Kanekafuji } \\ \text { Tenjin Ltd. } & \text { Kyocera }\end{array}$

as thin films have made no significant penetration of the power module market. Table 3.2 lists PV manufacturers using CZ technology in 1986.

Table 3.3 lists manufacturers using semicrystalline technology and Table 3.4 lists manufacturers using a-Si technology.

Only two companies, Entech and Intersol, are known to be shipping PV concentrators in 1986. Mobil Solar, Westinghouse of the United States and Toshiba of Japan are the only firms known to be shipping ribbon products in 1986 .

In summary, $\mathrm{CZ}$ and semicrystalline technologies are competing with each other for the same market sectors on the basis of price and efficiency. Both technologies are stable and reliable. Amorphous silicon has grown rapidly, primarily in the consumer goods market where efficiency and longevity are less important than in power module applications.

Amorphous silicon shipments have grown by carving out new market niches rather than by taking shares of established markets. Growth in the immediate future will likely follow this pattern. After a-Si efficiency, stability and reliability are adequately demonstrated, existing market sectors may become a serious target for a-Si penetration.

Concentrator and ribbon technologies are not significant factors in the market at this time; however, there is considerable interest in these technologies and they may become strong competitors in the future. 


\subsection{Market Sector Comparisons}

This section subdivides the annual shipments of PV modules by end-use. Estimating the shipments to these sectors is extremely difficult since modules are often sold by the manufacturer to distributors, importers or to other intermediates who then sell the modules to dealers or to the ultimate customers. In such cases, the original manufacturer may have little information on the end-use of the product.

The market sector designations used in this section resulted from a cooperative effort of Pacific Northwest Laboratory, the Jet Propulsion Laboratory and the Energy Information Administration. Definitions of the market sectors used are given below to assist the reader in interpreting the results.

End-use market sectors are used to help determine the amount of PV being installed in large and small, grid- vs. non-grid connected applications. These sectors are:

- Stand-alone applications-includes private residences, commercial systems, and agricultural

TABLE 4.1

Shipments to

End-Use Market Sectors (MW)

Sector $\quad 19801981198219831984 \underline{1985} 1986$

$\begin{array}{llllllll}\text { Stand-alone } & 2.6 & 3.9 & 4.3 & 7.4 & 10.2 & 11.0 & 12.5\end{array}$

Consumer

$\begin{array}{llllllll}\text { Products } & 0.4 & 0.9 & 1.5 & 3.6 & 4.9 & 6.7 & 9.3\end{array}$

Grid

\begin{tabular}{llllllll} 
Residential & 0.0 & $<.1$ & 0.1 & 0.2 & 0.3 & 0.3 & 0.4 \\
\hline
\end{tabular}

$\begin{array}{llllllll}\text { Intermediate } & 0.3 & 0.6 & 0.7 & 1.0 & 0.7 & 0.6 & 0.5\end{array}$

Central

$\begin{array}{llllllll}\text { Station } & 0.0 & 0.0 & 1.8 & 8.6 & \underline{5.5} & 1.9 & 2.0\end{array}$

Totals power systems that are not connected to an electrical power grid.

- Grid-connected residences-includes single- and multiple-family residences that generate a portion of the power they need and use the existing power grid for additional power. Any surplus power generated by the PV systems is sold back to the utility.

- Grid-connected, intermediate sized, commercial applications-includes power generation for use in local retailing, manufacturing, or service applications. Excess power is sold back to the utility.

- Central station-includes facilities that produce power for sale to local utilities as well as those owned by the utilities.

- Consumer products-includes PV used as power sources for calculators, watches, and small battery chargers as well as other small appliances.

Transportation applications are presently included in the stand-alone sector. In the future, these applications may grow to the point where they warrant a separate category. The present applications that are included are on boat- and land-based RV equipment.

The time series breakdown of market sectors by end-use is presented in Table 4.1.

The stand-alone equipment market continues to dominate all other markets, although the consumer products sector is growing rapidly and may overtake the stand-alone market. However, the standalone sector is a vigorous market growing at a rate of $33 \%$ per year, from 2.6 MW in 1980 to $12.5 \mathrm{MW}$ in 1986 (Figure 4.1). Over the same period, PV used in consumer products grew at a rate of $75 \%$ per year (Figure 4.2). Many stand-alone applications are far from saturated and continued growth is expected. PV-powered hand calculators may be beginning to saturate the market as they are now beginning to appear as a commercial courtesy, giveaway item. However, there appears to be a vast potential market for other consumer products using PV. 
FIGURE 4.1

PV Shipments to the

Stand-Alone Market Sector

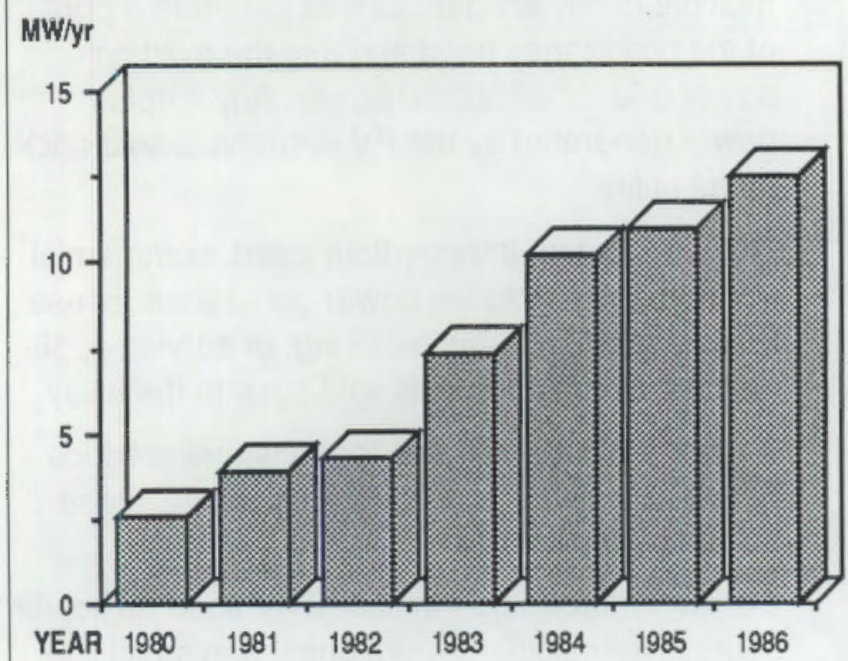

FIGURE 4.2

PV Shipments to the

Consumer Market Sector

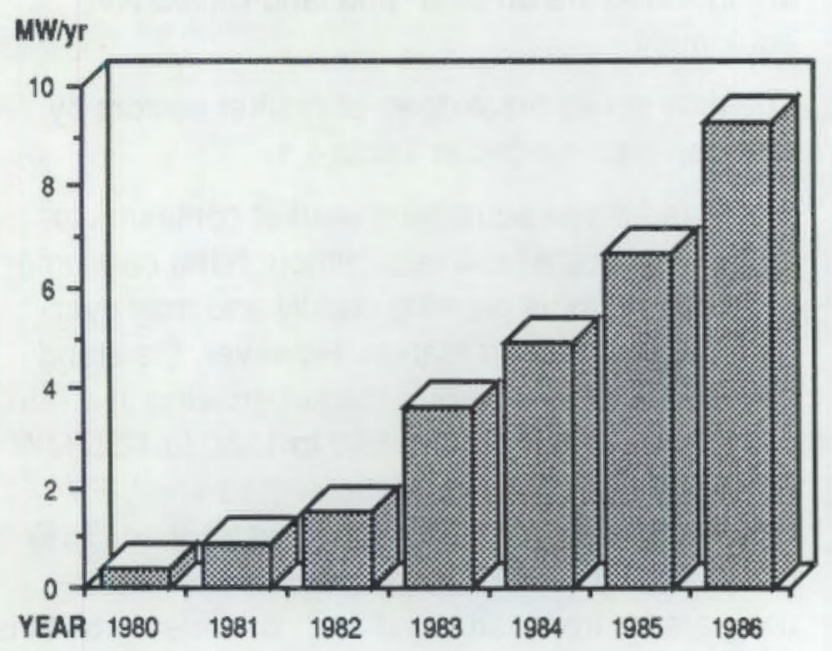

The stand-alone market segment can be further segmented into the following types of applications listed in their approximate order of decreasing importance:

- Communication

- Village power and lighting

- Pumping

- Cathodic protection.

Communication and cathodic protection are usually provided by: original equipment manufacturers (OEMs). These customers often repeat orders. The other sectors require a dealer or distributor to invest time in designing or customizing nearly every application.

Total grid-connected shipments, including grid residential, grid intermediate and central station, rose to a peak of nearly $10 \mathrm{MW}$ in 1983 (Table 4.2). The federal legislative climate became less favorable for tax breaks or other support for PV; this caused drastic reductions in the U.S. gridconnected market sectors. Japan and some European countries are continuing some support for these market segments.

In summary, the stand-alone and consumer goods markets will likely continue to expand at a modest rate in the future with or without any government support. The potential for stand-alone applications appears to be extremely large, but marketing managers say that PV still requires substantial customer education for each sale. However, they say that PV is no longer a totally strange idea, and some customers, such as communications equipment suppliers place repeat orders. Utilities and EPRI closely follow price reduction progress and could become major purchasers of PV generation equipment in 3-6 years.

TABLE 4.2

Grid-Connected PV Shipments

$\begin{array}{lcccccccc} & 1980 & 1981 & 1982 & 1983 & 1984 & 1985 & 1986 \\ \text { Concentrator } & 0.0 & 0.3 & 0.9 & 4.6 & 3.1 & 0.1 & 0.0 \\ \text { Flat Plate' } & \underline{0.3} & 0.3 & 1.7 & \underline{5.2} & \underline{3.4} & 2.7 & \underline{2.9} \\ \text { Totals } & 0.3 & 0.6 & 2.6 & 9.8 & 6.5 & 2.8 & 2.9\end{array}$



of World PV Shipments

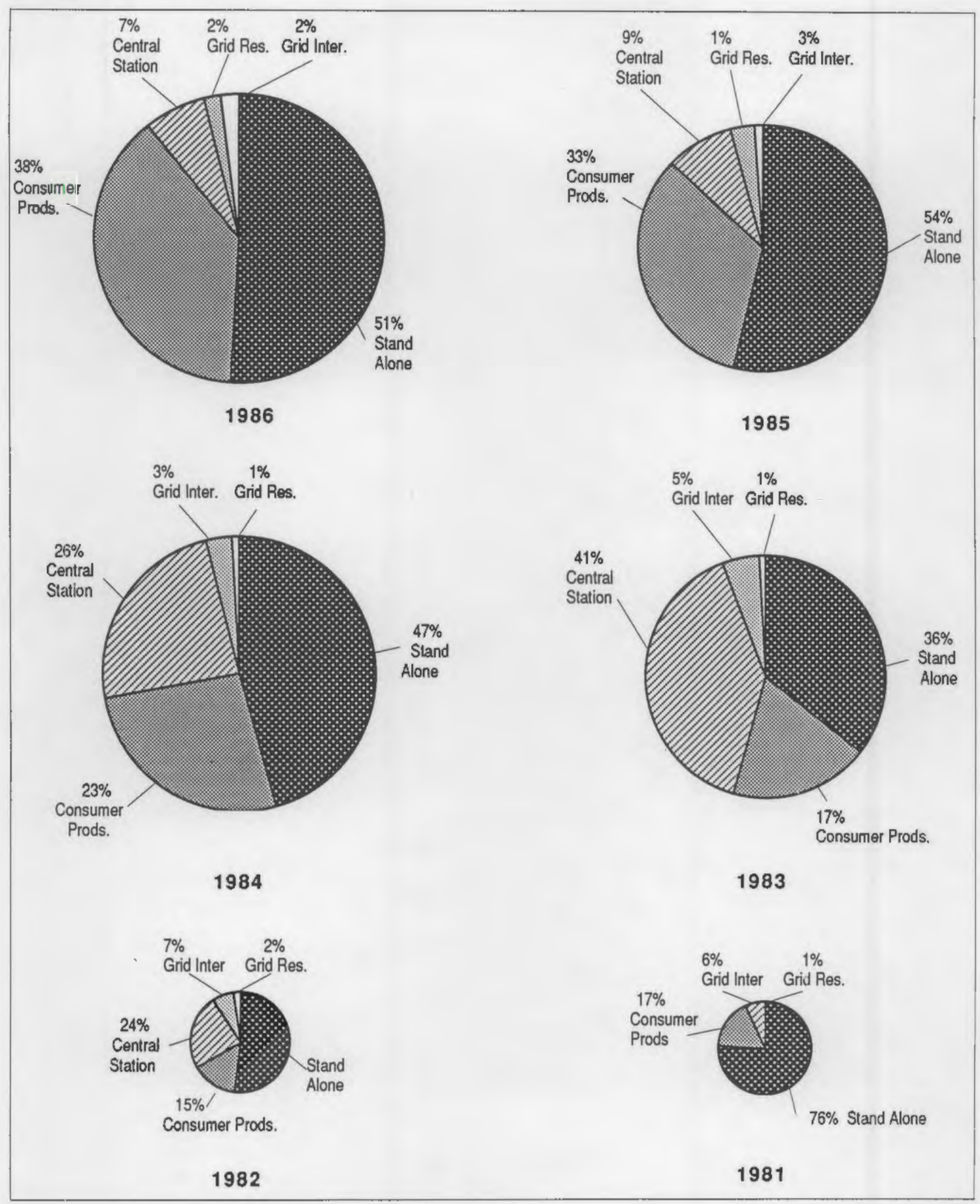





\section{DISTRIBUTION}

No. of

Copies

Offsite

30 DOE Technical Information

R.H. Annan

Photovoltaic Energy Technology Division

Department of Energy

600 E. Street, NW

Washington, D.C. 20585

50 A.D. Krantz

U.S. Department of Energy

Forrestal Building

Washington, D.C. 20585

M.B. Prince

U.S. Department of Energy

Forrestal Building

Washington, D.C. 20585

V.N. Rice

U.S. Department of Energy

Forrestal Building

Washington, D.C. 20585

E.C. Boes

Sandia National Laboratories

Albuquerque, NM 87185

P. Glaser

Arthur D. Little, Inc.

Acorn Park

Cambridge, MA 02140

Office of Mgmt. \& Budget

OMB Room 8002

New Executive Office Building

726 Jackson Place, NW

Washington, D.C. 20503

P.D. Maycock

Photovoltaic Energy Systems, Inc.

Box 290

Casanova, VA 22017

R.R Ferber

JPL (Jet Propulsion Laboratory)

California Institute of Technology

4800 Oak Grove Drive

Pasadena, CA 91109
No. of

Copies

Offsite

G. D. Self

Chronar

P.O. Box 177

Princeton, NJ 08540

R. Little

Spire Corporation

Patriots Park

Bedford, MA 01730

J. H. Caldwell

ARCO Solar

20554 Plummer Street

Chatsworth, CA 91311

T. Dyer

ARCO Solar

20554 Plummer Street

Chatsworth, CA 91311

M.L. Ream

Solarex Corporation

1335 Piccard Drive

Rockville, MD 20850

H.J. Saenger

Tideland Signal Corp.

4310 Directors Row, Box 52430

Houston, TX 77052

B.M. Gillespie

Mobil Solar Energy

4 Suburban Park Drive

Billerica, MA 01821

I.M. Shahrayer

Solec International

12533 Chadron Street

Hawthom, CA 90250

R.E. Curry

Photovoltaic Insiders Report 1011 Colorado Blvd.

Dallas, TX 75208

M. Uroshevich

Alpha Solarco

600 Vine Street

Cincinnati, OH 45202 
No. of

Copies

K.L. Porter

Renewable Energy 1001 Connecticut Ave., N.W.

Washington, D.C. 20036

A.L. Frank

International Solar Energy

Intelligence Report

BPI

951 Pershing Drive

Silver Spring, MD 20910

M. Polsky

Energy Systems Business

Management Organization

AT\&T Technology Systems

650 Liberty Avenue

P.O. Box 374

Union, NJ 07083
No. of

Copies

K. Shimada, Field Center Jet Propulsion Laboratory California Institute of Technology 4800 Oak Grove Drive Pasadena, CA 91109

J.L. Stone

Solar Energy Research Institute 1617 Cole Blvd.

Golden, CO 80401

Onsite

DOE Richland Operations Office

J.J. Sutey

65 Pacific Northwest Laboratory

R.L. Watts (50)

S.A. Smith (6)

B.L. Mohler

B.A. Garrett

Publishing Coordination (2)

Technical Information (5) 